\title{
Toronto 2010
}

\author{
By Brandon Wee
}

Fall 2010 Issue of KINEMA

\section{TORONTO INTERNATIONAL FILM FESTIVAL 2010 HIGHLIGHTS}

Having leapt into the exclusive club of industry film festivals of late, the Toronto International Film Festival nevertheless marked a transitional phase this year when it unveiled the Bell Lightbox, a donated piece of downtown real estate that is now home for year-round public programming and events. And in a shift indicative of its ambition, programming for TIFF's $35^{\text {th }}$ edition (9-19 September 2010) hinted at a desire to distinguish itself from a growing pool of international rivals. Though its annual selection of films from Asia is usually conservative, this year's crop of titles was notable for bringing into relief the intricacies of intra-Asia and transnational cooperation among filmmakers. Here's a look back at ten notable titles:

13 Assassins (Miike Takashi, Japan 2010)

Coming off as more square - but no less wildly entertaining - than many of his previous films, Miike Takashi's latest samurai epic is an eponymous remake of Kudo Eiichi's 1963 period drama, and also evocative of the myriad Chushingura stories behind the legacy of the ancient Forty-seven Ronin tale. Kôji Yakusho heads the cast of a 13-man detail tasked to execute a hit on a sadistic lord whose misdeeds and ambition are feared to embarrass his Shogunate family. While TIFF's cataloguing of this title under its 'Masters' section represented a nod to Miike's industrious body of work, its place in the programme emphasized the festival's conservatism.

Beautiful Boy (Shawn Ku, USA 2010)

When a gun-toting kid scores his fifteen minutes of fame by fatally shooting his schoolmates, the tragedy's narrative is often built from third party witness accounts. Shawn Ku's study of a fictional massacre instead trains a reverse shot on the estranged parents of a teenager who has just done the unthinkable. Maria Bello and Michael Sheen take us ably through the drama of middle class meltdown that likely typifies such tragedies. The result is a gripping perspective that is not only poignant, but more importantly, one valuable for the empathy rarely accorded to the perpetrator's next of kin.

Blame (Michael Henry, Australia 2010)

To settle a lingering score, five youths plan to kill a man and disguise his death as suicide, only to have their plans go woefully astray. Michael Henry's debut feature enters cautiously into the grand genre of Imperfect Crimes with a well-crafted thriller that doesn't pretend its dark twists and turns to be anything but humble stabs at suspense. While the plot is cluttered with hiccups, it leverages on compunction and misadventure to stage its showdown, just as many coming before it have done. For more cynical viewers, too many kids will of course spoil the crime scene.

Confessions (Nakashima Tetsuya, Japan 2010)

Upon learning the identities of the two students responsible for her young daughter's death, a high school teacher (Matsu Takako) swears revenge before her unruly class while shrewdly refusing to name them. But far from being a standard revenge flick, Nakashima Tetsuya's sleeper hit works hard to appeal viscerally and intellectually, its heady mix of social commentary and multiple narratives culminating in a clever payoff. Adapted from Minato Kanae's 2008 novel, this outstanding thriller recalls elements of Iwai Shunji's All About Lily Chou-Chou (2001) and Fukasaku Kinji's Battle Royale (2000). Its soundtrack, a generous medley of tunes, is simply hypnotic.

Essential Killing (Jerzy Skolimowski, Hungary/Ireland/Norway/Poland 2009)

Jerzy Skolimowski's latest film unfolds as a rare exercise in visual exposition and adopts a narrative pared down to abstracts. Vincent Gallo plays an anonymous man who is captured by Western military forces in the Middle East and then detained at an allied facility in Europe, where he soon escapes and is duly hunted across the continent's frigid woodlands without mercy. Skolimowski's purely pictorial strategy is designed to impale the attention, as is the story's thinly disguised political nature, which seeks viewer empathy for its hero. Emmanuelle Seigner rounds up the small cast in a cameo as a compassionate soul. 
Genpin (Kawase Naomi, Japan 2010)

Kawase Naomi's modest but powerful documentary introduces a small colony of natural childbirth adherents located in Okazaki, central Japan, and headed by Dr. Yoshimura Tadashi, an obstetrician/gynecologist turned semi-apostate who has since been championing the practice of natural childbirth without medical intervention. By all accounts running a bona fide maternity clinic, Yoshimura nevertheless is critical of obstetrics, which he claims robs women from experiencing nature's preeminent organic process in its most authentic form. The film's title derives from Laozi's description of a mysterious valley spirit who personifies the source of a large life-inducing river, which he likens to a woman.

Gorbaciof - The Cashier Who Liked Gambling (Stefano Incerti, Italy 2010)

Stefano Incerti's widely praised drama is really a pedestrian stroll in the park, about a churlish Neapolitan prison clerk (Toni Servillo) named Gorbaciof who acquits his dishonest gambling habit by saving a woman he thinks is vulnerable. His object of affection is Lila (Yang Mi), a demure Chinese immigrant whose father (Hal Yamanouchi) Gorbaciof is convinced will betray her modesty to settle debts similar to his. But since Lila and her father have been reduced to speechless characters, they remain at the mercy of one man's prejudice and dangerous fantasy. Gorbaciof gets his nickname from a splotch on his forehead.

I Saw the Devil (Kim Jee-woon, South Korea 2010)

Kim Jee-woon's spin on the revenge flick sees Lee Byung-hun's violent cop out for vigilante justice after learning Choi Min-shik is the deranged predator behind his fiancée's murder. This is skilfully directed suspense in which the two take turns playing cat and mouse, although the midpoint hints at who will laugh last. TIFF screened the Director's Cut, eclipsing the milder version for the South Korean release. Nevertheless, Kim's remark in Toronto that some viewers have found the brutality too tame is accurate. (For a more gratuitous and disturbing take on gore alone, see this year's Dream Home by Pang Ho-cheung.)

Norwegian Wood (Tran Anh Hung, Japan 2010)

It had to come sooner or later. Tran Anh Hung's adaptation of Murakami Haruki's hit 1987 novel tells of a man's (Matsuyama Ken'ichi) reminiscence of student life in 1960s Tokyo, but especially his relationship with two women: Naoko (Kikuchi Rinko), whom he falls for after his buddy's suicide leaves her single, and Midori (Mizuhara Kiko), a libertine chick he hooks up with in between Naoko's treatment for grief out of town. Tran's strategy of allowing the material to breathe (too much occasionally) results in a thoughtful and moving story, but the film's revelation is Kikuchi, whose performance is startlingly good.

Special Treatment (Jeanne Labrune, Belgium-France-Luxembourg 2010)

Jeanne Labrune's unassuming look at the liaison between a hooker and a shrink whose dreadful lives cross paths is often funny for its host of narrative setups and punch lines despite an otherwise downbeat tone. While Isabelle Huppert's Alice is an upmarket call girl who is having second thoughts about continuing her line of work, uptight and overweight Xavier (Bouli Lanners) is the jaded psychoanalyst who is frustrated by his marriage's impending collapse. Perhaps the story's most subliminal wink to justify their inevitable encounter is that each needs the other for some kind of release, be it business or pleasure.

\section{Author Information}

Brandon WEE lives in Toronto. He has written for Asia Pacific Arts (Los Angeles), Cineaste (New York), Cinema Scope (Toronto), Ricepaper (Vancouver), and Senses of Cinema (Melbourne). 